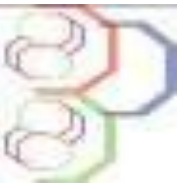

Journal of Applied Biosciences 158: 16332 - 16339

ISSN 1997-5902

\title{
Biochemical composition and sensory characteristics of infusions of leaves from two morphotypes of Lippia multiflora (verbenaceae) grown in Côte d'Ivoire
}

\author{
Kane Fako1*, Djina Yves ${ }^{1}$, Brou Koffi Siméon², Gonnety Tia jean ${ }^{1}$ \\ ${ }^{1}$ Laboratoire de Biocatalyse et des Bioprocédés, UFR STA, Université Nangui Abrogoua, Abidjan, Côte d'Ivoire \\ ${ }^{2}$ Laboratoire de Biochimie Alimentaire et de Technologie des Produits Tropicaux, UFR STA, Université Nangui \\ Abrogoua, Abidjan, Côte d'Ivoire \\ Corresponding author email: kanefako@yahoo.fr
}

Original submitted in on 18 th December 2020. Published online at www.m.elewa.org/journals/ on $28^{\text {th }}$ February 2021 https://doi.org/10.35759/JABs.158.7

\begin{abstract}
Objectives: this study aims to compare composition and sensorial characteristics of infusions of leaves from broad leave morphotype (blmLM) and long leave morphotype (IImLM) of Lippia multiflora (Savannah tea) cultivated in three localities, in order to identify the morphotype and/or locality, which offer the better biochemical composition and organoleptic qualities of tea.

Methodology and results: Leaves harvested were dried and pulverized. Infusions were prepared using standard methods and sensorialy analysed by Mossion methods. Elements were determined according to AOAC methods. Phenolics compounds and caffeine was analysed by a standard method. Infusions of blmLM are rich in tannins $(12.15-14.26 \mathrm{mg} / \mathrm{L})$, quercetin $(0.33-0.95 \mathrm{mg} / \mathrm{L})$ and flavanone $(05.75-13.33 \mathrm{mg} / \mathrm{L})$, while those of $I \mathrm{ImLM}$ are rich in caffeine (19.07-20.14 mg/L) and catechin (08.89-59.56 mg/L). Calcium (50.96$51.54 \mathrm{mg} / \mathrm{L})$ and magnesium (35.10-37.08 mg/L) contents are highest in infusions of BlmLM, while $\| \mathrm{mLM}$ infusions are richer in $\mathrm{K}(97.78-103.46 \mathrm{mg} / \mathrm{L})$ and $\mathrm{Na}(143.01-156.03 \mathrm{mg} / \mathrm{L})$. Globally, infusions are brown to greenish yellow, astringent, slightly bitter with a pleasant smell. Infusions of Béoumi and Korhogo have a mint scent; those of Béoumi have a scent of lemongrass.

Conclusion and Application of results: The qualities of infusions depend on the morphotype and the growing area. Their richness in phenolic compounds, caffeine and essential minerals gives them nutritional, medicinal and pharmacological properties and can be a replacement for ordinary teas sold on the market. This study provides information on the choice of the plant morphotype and the cultivation area according to the needs of the consumer. Consumption of infusions of leaves from Korhogo and Béoumi that are richer in tannins, catechin, quercetin and essential minerals (calcium, magnesium and iron) will be beneficial for human nutrition, bones strengthening and prevention of cardiovascular diseases which represent a public health problem. Taking Lippia multiflora into account in the agricultural and eating habits of farmers will constitute for them a source of income and also a source of permanent raw material for the agro-food processing industries.
\end{abstract}

Keywords: Lippia multiflora, leaves infusion, biochemical composition, sensory characteristics 


\section{INTRODUCTION}

Tea is an infusion of Camellia sinensis leaves, which is the most consumed beverage in the world after water because of its medicinal and nutritional properties (Senthilkumar et al., 2015). However, apart from Camellia sinensis, several other plants such as Cymbopogon citratus and Lippia multiflora are used as tea because of their pleasant odour. Lippia multiflora belonged to the verbenaceae that is a large family with about 70 to 80 genera and over 3000 species. It is a perennial and aromatic shrub mainly distributed in tropical Africa, South America and Central America (Kunle \& Egharevba, 2012). In Côte d'Ivoire, it grows in the center, north and northeast (Hien et al., 2012). Thus, because of this adaptability to different ecosystems and different soils types, Lippia multiflora presents morphological variability called "morphotypes ". Alui et al. (2011) through their studies on the agronomic characteristics of different morphotypes of the plant,

\section{MATERIAL AND METHODS}

Characteristic of the different study sites: The study was carried out in three localities of Côte d'Ivoire, which are Béoumi (Center), Bondoukou (East) and Korhogo revealed two main morphotypes: plants with oblong, rigid, long, dark green leaves and plants with elliptical, shiny leaves, short, light green in colour. From a chemical point of view, the essential oils of Lippia multiflora have been largely characterized. Several authors indicated that their chemical composition is influenced by plant origin and genetic factors (Mann, 2014). However, literature on other biochemical components of leaves, such as alkaloids, polyphenols (flavonoids, tannins and catechins) and minerals, is very rare. This study aims to compare caffeine, phenolic and mineral composition of the leaves of two morphotypes: long leaves morphotypes ( $I m \mathrm{~L} \mathrm{~L})$ and broad leaves morphotype (b/mLM) of Lippia multiflora cultivated in Côte d'Ivoire as well as their infusions. The objective is to identify the morphotypes and localities, which offer leaves of better organoleptic qualities for the preparation of tea.

(North), chosen on the basis of their differences from pedoclimatic point of view ( table 1).

Table 1. Natural characteristics of the study sites

\begin{tabular}{l|c|c|c}
\hline \multirow{2}{*}{\multicolumn{1}{l|}{ Characteristics }} & \multicolumn{3}{c}{ Localities of culture } \\
\cline { 2 - 4 } \multicolumn{1}{l}{ Latitude } & Béoumi & Bondoukou & Korhogo \\
longitude & $7^{\circ} 42^{\prime} 28^{\prime \prime} \mathrm{N}$ & $8^{\circ} 06^{\prime} 43^{\prime \prime} \mathrm{N}$ & $9^{\circ} 23^{\prime} 23^{\prime \prime} \mathrm{N}$ \\
\hline Annual rainfall $(\mathrm{mm})$ & $5^{\circ} 35^{\prime} 50^{\prime \prime} \mathrm{O}$ & $2^{\circ} 42^{\prime 2} 3^{\prime \prime} \mathrm{O}$ & $5^{\circ} 48$ "490 \\
\hline Annual average temperature $\left({ }^{\circ} \mathrm{C}\right)$ & 1200 & 1100 à 1700 & 1000 à 1200 \\
\hline Climate & 25,4 & 22 à 27 & 26 \\
\hline Relative humidity $(\%)$ & Baouléen & Baouléen & Soudanais \\
\hline Natural vegetation & 75 & 80 & 61,5 \\
\hline \multirow{2}{*}{ Soil types } & Tree savannah & Tree savannah & Shrubby savannah \\
\hline
\end{tabular}

Plan material and experimental device of plots: The plants were grown in the three agro-ecological zones described above (Table 1). The experimental design was a complete random block with two replicates for each morphotype. The $400 \mathrm{~m}^{2}$ plot at each test site was subdivided into 6 sub-plots measuring $54 \mathrm{~m}^{2}(9 \mathrm{mx} 6 \mathrm{~m})$ containing 45 feet of plant, maintained by regular weeding.

Sampling: Leaves were harvested according to the fine picking method as described by Owuor \& Kwach (2012).
Leaf sample were dried in the open air out of the sun for a week and pulverized using a Blender FAR BL514X Cl mixer to obtain a fine dry powder that was stored in sealed plastic boxes.

Method of preparing the infusion: Leaves samples (5 g) were infused with $250 \mathrm{~mL}$ freshly boiled deionized water for five minute. The resulting solution was filtered through filter paper (Whattman No. 42) and then poured into $250 \mathrm{~mL}$ tea tasting porcelain bowl for quality assessment (Adnan et al, 2013). 
Mineral composition analysis: Minerals in infusions such as calcium, magnesium, sodium, potassium, phosphorus, copper, manganese, iron and zinc were determined by Atomic Absorption spectrophotometer, according to standard methods of AOAC (2000).

Analysis of caffeine and phenolic compounds by HPLC: Phenolic compounds and caffeine was performed according to method of Donovan et al. (1998). The sample and standard solutions were filtered through Whattman paper $0.45 \mu \mathrm{m}$, and then through millipore membrane $0.45 \mu \mathrm{m}$ (CARL ROTH, Karlsruhe, Allemagne). The equipment used is a HPLC (Shimadzu, France) system provided with a binary pump (LC-20A) coupled with a UV-VIS detector (SPD-20A). The used column (Thero, Runcom, England) for this analysis was Hypersil ODS type C18, $250 \mathrm{~mm}$ x $4.6 \mathrm{~mm}, 5 \mu \mathrm{m}$ (Thero, Runcom, England). The separation was carried out in elution gradient. The used mobile phase consisted of 50 $\mathrm{mM} \mathrm{NH4H2PO4}$ at $\mathrm{pH} 2.6$ (solvent A), acetonitrile solution/ NaH2PO4 (80:20, VN) (solvent B) and $200 \mathrm{mM}$ o-phosphoric acid at pH 1.5 (Solvent $\mathrm{C}$ ). The flow rate was $0.5 \mathrm{~mL} / \mathrm{min}$. Elution profile was as follows: $100 \% \mathrm{~A}$ for $0-5 \mathrm{~min}, 92 \% \mathrm{~A} / 8 \% \mathrm{~B}$ for $5-8 \mathrm{~min} ; 14 \% \mathrm{~B} / 86 \% \mathrm{C}$ for $8-20 \mathrm{~min} ; 16.5 \% \mathrm{~B} / 83.5 \% \mathrm{C}$ for $20-25 \mathrm{~min} ; 21.5 \%$ $\mathrm{B} / 78.5 \% \mathrm{C}$ for $25-35 \mathrm{~min}, 50 \% \mathrm{~B} / 50 \% \mathrm{C}$ for $35-70 \mathrm{~min}$ and $100 \% \mathrm{~A}$ for $70-75 \mathrm{~min}$. Each peak detected in the sample solutions was identified by comparing the retention time with chromatogram of reference substance.

Sensory evaluation of infusions: Sensory evaluation were realised at the Laboratory of Biocatalysis and Bioprocesses of Nangui Abrogoua University. Quantitative Descriptive Analysis was conducted by 12 trained judges to determine aroma, appearance, flavour and overall acceptability of infusions. Those parameters was analysed by the method of Mossion (2007), by assigning a score of between 0 and 20 for each descriptor, according to the sensitivities of panellists. Zero corresponds to little and 20 correspond to a lot. Products as references were also identified for each characteristic (Table 2). Panellists received three-digit randomized coded samples in a randomized and monadic order.

Table 2: References products offered for the different descriptors

\begin{tabular}{l|l}
\hline Odour & References \\
\hline Mint & Spearmint leaves \\
Lemongrass & Lemongrass leaves \\
Sweet & Vanilla powder \\
Fresh grass & Fresh cut grass \\
citrus & Lemon fruit \\
\hline Appearance & References \\
\hline Browning & Coffee solution \\
Yellow colour & Colour disc \\
\hline Flavour & References \\
\hline Bitterness & Caffeine solution \\
Acid & Lemon juice (citric acid) \\
Astringency & Green plantain banana \\
\hline
\end{tabular}

Statistical analyses of data: All analyses were performed in triplicate. The results were expressed as the mean \pm standard deviation. Analysis of variance (ANOVA) was performed to test the cultivation area on

\section{RESULTS}

Mineral composition: The infusions contain all the analysed minerals (table 3). Sodium (16.29 to 156.03 $\mathrm{mg} / \mathrm{L}$ ) is the most abundant mineral in infusions, followed by potassium (80.50-103.46 mg/L), calcium (39.76$54.04 \mathrm{mg} / \mathrm{L})$ and magnesium (15.91-37.08 mg/L). Phosphorus and the weakest macro-element present in biochemical composition. The means were compared using Duncan's test $(P \leq 0.05)$, using STATISTICA 7.1 software.

the infusions with a content varying from 3.09 to 3.77 $\mathrm{mg} / \mathrm{L}$. For the macro-elements $(\mathrm{Ca}, \mathrm{K}, \mathrm{Mg}, \mathrm{Na})$, a significant difference is observed $(P \leq 0.05)$ between the two morphotypes for each locality. Contents of copper, iron, zinc and manganese are less than $0.05 \mathrm{mg} / \mathrm{L}$ in infusions. 
Kane et al., J. Appl. Biosci. 2021 Biochemical composition and sensory characteristics of infusions of leaves from two morphotypes of Lippia multiflora (verbenaceae) grown in Côte d'Ivoire

Table 3: Mineral composition of infusions of leaves from IImLM and blmLM of Lippia multiflora from three agroecological zones (mg/L)

\begin{tabular}{c|c|c|c|c|c|c}
\hline Localities & \multicolumn{2}{|c|}{ Bondoukou } & \multicolumn{2}{c|}{ Korhogo } & \multicolumn{2}{c}{ Beoumi } \\
\hline Parameter & $\| m L M$ & $b l m L M$ & $\| m L M$ & $b l m L M$ & $\| m L M$ & blmLM \\
\hline $\mathrm{Ca}$ & $44.96 \pm 0.76^{\mathrm{b}}$ & $50.96 \pm 3.11^{\mathrm{c}}$ & $50.10 \pm 3.06^{\mathrm{c}}$ & $51.84 \pm 3.00^{\mathrm{c}}$ & $54.04 \pm 0.60^{\mathrm{c}}$ & $39.76 \pm 2.66^{\mathrm{a}}$ \\
$\mathrm{K}$ & $81.99 \pm 0.03^{\mathrm{c}}$ & $87.31 \pm 3.12^{\mathrm{cd}}$ & $97.78 \pm 1.46^{\mathrm{c}}$ & $91.50 \pm 6.89^{\mathrm{c}}$ & $103.46 \pm 3.91^{\mathrm{d}}$ & $80.50 \pm 1.75^{\mathrm{c}}$ \\
$\mathrm{Mg}$ & $27.41 \pm 3.26^{\mathrm{bd}}$ & $37.08 \pm 6.46^{\mathrm{c}}$ & $34.33 \pm 4.07^{\mathrm{cd}}$ & $35.10 \pm 4.43^{\mathrm{cd}}$ & $18.80 \pm 6.51^{\mathrm{ab}}$ & $15.91 \pm 4.91^{\mathrm{a}}$ \\
$\mathrm{Na}$ & $143.01 \pm 8.30^{\mathrm{bd}}$ & $127.81 \pm 1.87^{\mathrm{b}}$ & $156.03 \pm 4.84^{\mathrm{d}}$ & $124.84 \pm 7.08^{\mathrm{b}}$ & $116.29 \pm 1.57^{\mathrm{a}}$ & $136.46 \pm 1.57^{\mathrm{c}}$ \\
$\mathrm{P}$ & $3.09 \pm 0.18^{\mathrm{b}}$ & $3.41 \pm 0.22^{\mathrm{b}}$ & $3.46 \pm 0.04^{\mathrm{b}}$ & $3.29 \pm 0.12^{\mathrm{b}}$ & $3.77 \pm 0.13^{\mathrm{b}}$ & $3.29 \pm 0.08^{\mathrm{b}}$ \\
$\mathrm{Cu}$ & $0.002 \pm 0.00^{\mathrm{a}}$ & $0.014 \pm 0.01^{\mathrm{a}}$ & $0.090 \pm 0.11^{\mathrm{a}}$ & $0.017 \pm 0.00^{\mathrm{a}}$ & $0.072 \pm 0.09^{\mathrm{a}}$ & $0.022 \pm 0.00^{\mathrm{a}}$ \\
$\mathrm{Fe}$ & $0.003 \pm 0.00^{\mathrm{a}}$ & $0.0003 \pm 0.00^{\mathrm{a}}$ & $0.001 \pm 0 / 00^{\mathrm{a}}$ & $0.010 \pm 0.00^{\mathrm{ab}}$ & $0.001 \pm 0.00^{\mathrm{a}}$ & $0.002 \pm 0.00^{\mathrm{a}}$ \\
$\mathrm{Mn}$ & $0.13 \pm 0.01^{\mathrm{a}}$ & $0.19 \pm 0.01^{\mathrm{a}}$ & $0.27 \pm 0.05^{\mathrm{b}}$ & $0.21 \pm 0.01^{\mathrm{b}}$ & $0.17 \pm 0.00^{\mathrm{a}}$ & $0.15 \pm 0.00^{\mathrm{a}}$ \\
$\mathrm{Zn}$ & $0.13 \pm 0.17^{\mathrm{a}}$ & $0.09 \pm 0.01^{\mathrm{a}}$ & $0.28 \pm 0.23^{\mathrm{a}}$ & $0.32 \pm 0.27^{\mathrm{a}}$ & $0.75 \pm 0.15^{\mathrm{a}}$ & $0.03 \pm 0.00^{\mathrm{a}}$ \\
\hline
\end{tabular}

Each value is an average of three replicate. Values are mean \pm standard deviation. Means not sharing a similar letter in a line are significantly different $p=0.05$ as assessed by the test of Duncan. IImLM: longleaf morphotype of Lippia multiflora; blmLM: broadleaf morphotype og Lippia multiflora

Contents of caffeine and phenolics compound in infusions: Caffeine and phenolic compounds contents are depicted in table 4 . Results showed significant variability $(p<0.05)$ according to the morphotypes and agro-ecological zones. Caffeine content varies from 14.59 to $40.05 \mathrm{mg} / \mathrm{L}$, the highest level $(40.05 \mathrm{mg} / \mathrm{L})$ was observed with blmLM from Beoumi. IImLM from Korhogo showed the highest amount of catechin $(59.51 \mathrm{mg} / \mathrm{L})$, tannins $(14.33 \mathrm{mg} / \mathrm{L})$, and quercetin $(1.06 \mathrm{mg} / \mathrm{L})$, while the highest amount of flavanone $(13.33 \mathrm{mg} / \mathrm{L})$ were found in blmLM from Korhogo.

Table 4: Caffeine and phenolics contents of infusions from IImLM and blmLM of Lippia multiflora from three agroecological zones (mg/L)

\begin{tabular}{l|l|l|l|l|l|l}
\hline \multirow{2}{*}{ Parameter } & \multicolumn{3}{|l|}{ Bondoukou } & \multicolumn{2}{l|}{ Korhogo } & \multicolumn{2}{l}{ Beoumi } \\
\cline { 2 - 7 } & $\| \mathrm{mLM}$ & $\mathrm{b} / \mathrm{mLM}$ & $\| \mathrm{mLM}$ & blmLM & $\| \mathrm{mLM}$ & blmLM \\
\hline Caffeine & $20.14 \pm 0.05^{\mathrm{e}}$ & $18.57 \pm 0.03^{\mathrm{b}}$ & $14.59 \pm 0.03^{\mathrm{a}}$ & $14.59 \pm 0.02^{\mathrm{a}}$ & $19.07 \pm 0.01^{\mathrm{d}}$ & $40.05 \pm 0.01^{\mathrm{d}}$ \\
\hline Catechin & $08.89 \pm 0.05^{\mathrm{b}}$ & $06.21 \pm 0.01^{\mathrm{b}}$ & $59.51 \pm 0.10^{\mathrm{f}}$ & $37.97 \pm 0.01^{\mathrm{f}}$ & $19.07 \pm 0.02^{\mathrm{d}}$ & $12.94 \pm 0.02^{\mathrm{c}}$ \\
\hline Tannins & $11.95 \pm 0.09^{\mathrm{e}}$ & $12.15 \pm 0.31^{\mathrm{d}}$ & $14.33 \pm 0.28^{\mathrm{f}}$ & $07.16 \pm 0.06^{\mathrm{a}}$ & $06.02 \pm 0.50^{\mathrm{a}}$ & $14.26 \pm 0.09^{\mathrm{e}}$ \\
\hline Flavanone & $06.11 \pm 0.15^{\mathrm{e}}$ & $05.75 \pm 0.05^{\mathrm{c}}$ & $04.02 \pm 0.55 \mathrm{~b}^{\mathrm{c}}$ & $01.95 \pm 0.11^{\mathrm{a}}$ & $04.25 \pm 0.15^{\mathrm{cd}}$ & $13.33 \pm 0.08^{\mathrm{e}}$ \\
\hline Quercetin & $0.23 \pm 0.01^{\mathrm{a}}$ & $0.73 \pm 0.01^{\mathrm{b}}$ & $1.06 \pm 0.01^{\mathrm{c}}$ & $0.74 \pm 0.01^{\mathrm{b}}$ & $0.25 \pm 0.33^{\mathrm{a}}$ & $0.95 \pm 0.01^{\mathrm{c}}$
\end{tabular}

Each value is an average of three replicate. Values are mean \pm standard deviation. Means not sharing a similar letter in a line are significantly different $p=0.05$ as assessed by the test of Duncan. IImLM: longleaf morphotype of Lippia multiflora; blmLM: broadleaf morphotype og Lippia multiflora

Sensory evaluation and sensorial profiles of infusions: After the sensory analysis, the parameters most perceived by the panellists with a score greater than 8 were considered important and taken into account for the representation of the sensory profile of the infusions of each morphotype are recorded in table 5.
Flavour: Bitterness is weakly perceived in all infusions with marks from 6.25 to 9.83 . There is no significant difference $(P \leq 0.05)$ between the culture zones and the morphotypes. Astringency is a sensation that was also detected in all infusions with a significant difference $(P \leq 0.05)$ between culture areas and morphotypes. Regarding the morphotypes, the average marks vary 
from 9.75 to 10.50 for blmLM and from 8.50 to 12.00 for IImLM. In general, in each of the localities, the infusions of the blmLM are more astringent than those of the IImLM.

Appearance: The most pronounced appearance characters of infusions are: coffee, limpid, yellow, green and bright (Table 5). In all localities, the brown (coffee) colour is more pronounced in infusions of $\| \mathrm{mLM}$ compared to those of blmLM. As for the "yellowish" colour, it is seen in all infusions at significantly varying intensity $(P \leq 0.05)$, between the cultivation areas. Indeed, Beoumi infusions are more yellowish compared to those of Bondoukou and Korhogo. However, in the same locality, there is no significant difference between the morphotypes. The green colouring is also seen in all infusions with varying intensities. For this character, the scores vary significantly $(P \leq 0.05)$, depending on the growing area. Thus, the infusions of Korhogo are more greenish compared to those of Bondoukou and Beoumi. For each, there is no difference between the morphotypes.

Aroma: Concerning the olfactory descriptors, the aromas of "mint" and "lemongrass" were the most dominant scents in all the infusions to varying degrees. For each character, there is a significant difference between the cultivation areas. The highest scores for the "mint" aroma (11.50-12.91) were obtained with the infusions of Béoumi and Korhogo, while the infusions of Bondoukou had the highest scores for the "lemongrass" aroma (13.41-15.50). These results show that Béoumi and Korhogo leaves have a "mint" aroma, while those of Bondoukou have a "lemongrass" aroma. In each of the localities, the averages are roughly identical regardless of the morphotype, showing that the aroma depends very little on the variety of the plant. Sensorial profile of infusion of each the morphotype represented by figure 1 (a \& b) was established taking into account the main descriptors wich obtained the highest scores by the panellists. The profiles show that whatever the morphotype, the infusions of Beoumi and Korhogo have an aroma of mint, while those of Bondoukou have an aroma of lemongrass. In addition, the Bondoukou infusion is much more astringent compared to those of the other two localities. In addition, while Bondoukou and Korhogo infusions have a more greenish colour, Beoumi's is more yellowish regardless of the morphotype.

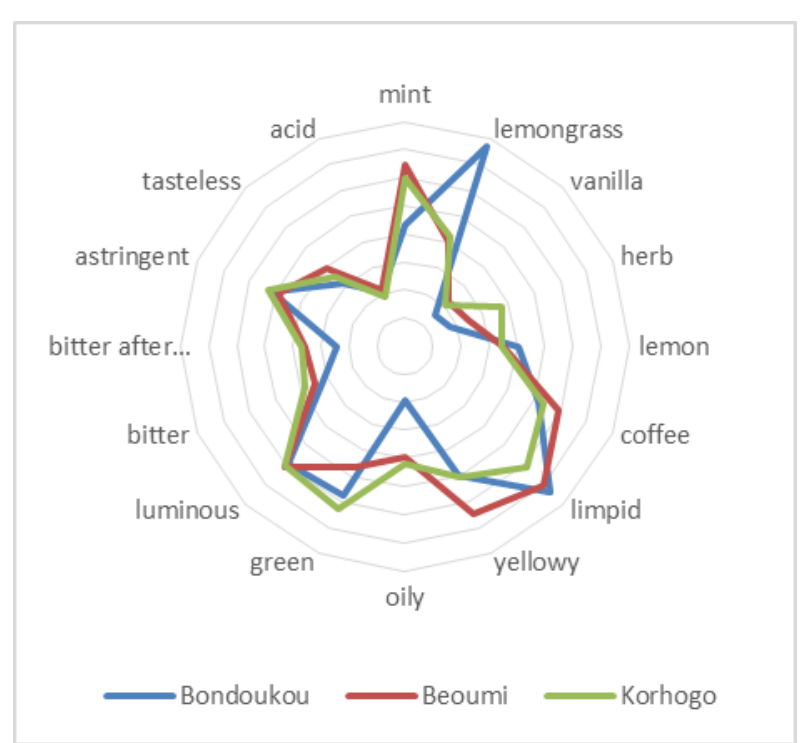

(a) blmLM

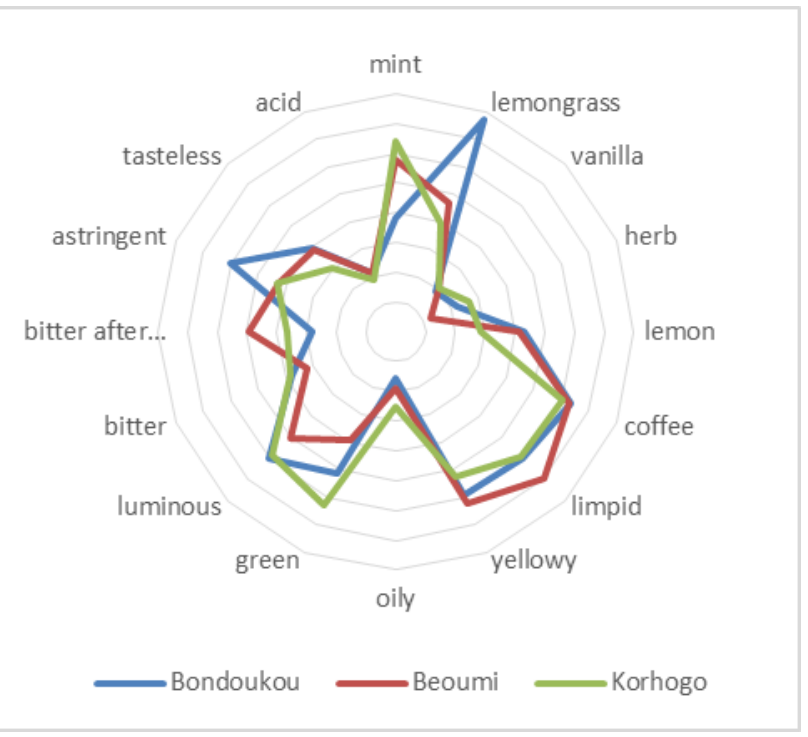

(b) IImLM

Figure 1. Sensory profiles of infusions of the leaves from the broad leaf (blmLM) and long leaf (IImLM) morphotypes of Lippia multiflora, cultivated in three localities in Côte d'Ivoire 
Table 5. Notes on the flavour, appearance and aroma descriptors of the infusions of the two morphotypes according to the cultivation area

\begin{tabular}{|c|c|c|c|c|c|c|c|}
\hline & \multicolumn{2}{|c|}{ Bondoukou } & \multicolumn{2}{|c|}{ Beoumi } & \multicolumn{2}{|c|}{ Korhogo } \\
\hline & & $\| \mathrm{mLM}$ & blmLM & $\| \mathrm{mLM}$ & blmLM & $\| \mathrm{mLM}$ & blmLM \\
\hline \multirow{2}{*}{ Flavour } & Bitter & $6.25 \pm 1.43^{a}$ & $7,58 \pm 0,86^{a b}$ & $7.00 \pm 0.93^{a}$ & $6.50 \pm 1.20^{a}$ & $7.66 \pm 1.20^{\mathrm{ab}}$ & $7.66 \pm 1.20^{\mathrm{ab}}$ \\
\hline & Astringency & $10.25 \pm 1.19 \mathrm{ab}$ & $12.00 \pm 0.76^{e}$ & $9.75 \pm 1.28^{c}$ & $8.50 \pm 0.93^{\mathrm{ab}}$ & $10.50 \pm 1.46^{d}$ & $8.58 \pm 1.46^{b}$ \\
\hline \multirow{4}{*}{ Appearance } & Brown (coffee) & $10.33 \pm 0.91^{\mathrm{a}}$ & $12.75 \pm 0.63^{c}$ & $11.83 \pm 0.93^{a b c}$ & $12.58 \pm 0.67^{\mathrm{bc}}$ & $10.66 \pm 1.87^{a b}$ & $12.08 \pm 1.97^{a b c}$ \\
\hline & Limpid & $14.75 \pm 0.81 \mathrm{bc}$ & $12.08 \pm 0.91 \mathrm{abc}$ & $14.00 \pm 1.07^{b c}$ & $14.00 \pm 0.78^{\mathrm{bc}}$ & $12.25 \pm 0.93^{a}$ & $11.91 \pm 1.09^{a}$ \\
\hline & Yellowy & $10.00 \pm 0.90^{\mathrm{abcd}}$ & $11.91 \pm 0.97^{\mathrm{bcd}}$ & $12.91 \pm 1.05^{d}$ & $12.50 \pm 1.26^{\mathrm{bc}}$ & $10.16 \pm 0.74^{\mathrm{abc}}$ & $10.50 \pm 1.15^{\mathrm{abcc}}$ \\
\hline & Green & $11.58 \pm 1.10^{\mathrm{abc}}$ & $10.25 \pm 0.94^{\mathrm{bcd}}$ & $9.33 \pm 1.09 \mathrm{~cd}$ & $7.91 \pm 1.15^{\mathrm{d}}$ & $12.50 \pm 1.11^{a}$ & $12.66 \pm 0.89^{a b}$ \\
\hline \multirow{2}{*}{ Aroma } & Mint & $8.58 \pm 0.99 \mathrm{bcd}$ & $7.66 \pm 0.83^{b}$ & $12.91 \pm 1.50^{\mathrm{bc}}$ & $11.50 \pm 1.40^{\mathrm{bc}}$ & $11,91 \pm 0,92^{\text {acd }}$ & $12,58 \pm 1,11^{a}$ \\
\hline & lemongrass & $15.41 \pm 1.17^{b}$ & $15.50 \pm 0.97^{b}$ & $8.08 \pm 1.19^{b}$ & $9.41 \pm 0.83 b$ & $8.50 \pm 1.37^{\mathrm{ab}}$ & $7.91 \pm 1.25^{\mathrm{a}}$ \\
\hline
\end{tabular}

Each value is an average of three replicate. Values are mean \pm standard deviation. Means not sharing a similar letter in a line are significantly different $p=0.05$ as assessed by the test of Duncan. blmLM: broadleaf morphotype of Lippia multiflora; IImLM: longleaf morphotype of Lippia multiflora 


\section{DISCUSSION}

Mineral composition: The main form of food use of $L$. multiflora leaves is infusion and decoction (Kunle \& Egharevba, 2012). Mineral elements in the aqueous extracts are considered an asset for the health of the consumer, their presence reflects the nutritional value of the infusion of Lippia multiflora and its benefit for the health. The calcium, magnesium and sodium contents obtained in this study are higher than those determined by Mayouf et al. (2015) in infusion of $C$. sinensis.

Contents of caffeine and phenolics compound in infusions: Caffeine contents found in this study are lower than those found by Adnan et al. (2013) in the infusion of $C$. sinensis, which vary from 38 to $40.6 \mathrm{mg} / \mathrm{L}$. The tannin contents $(6.02$ of $14.33 \mathrm{mg} / \mathrm{L})$ are lower than those found by Chakrabarty et al. (2017) in infusion of $C$. sinensis leaves $(22 \mathrm{mg} / \mathrm{L})$. Difference between morphotypes at the same site may be explained by the specific metabolic behavior of each morphotype with respect to environmental factors, in accordance with the findings made by Anuraga et al. (1993) in the genus Lotus. The catechin contents $(6.21$ to $59.51 \mathrm{mg} / \mathrm{L})$ infusions of $L$. multiflora are much higher than those of the leaves of $C$ sinensis $(3.31 \mathrm{mg} / \mathrm{L}$ ) reported by Oliveira (2012). Quercetin and flavanones of has been previously revealed in the leaves of $L$. multiflora and they are with tannins and catechins responsible of the medicinal and

\section{CONCLUSION AND APPLICATION OF RESULTS}

The qualities of infusions depend on the morphotype and the growing area. Their richness in phenolic compounds, caffeine and essential minerals gives them nutritional, medicinal and pharmacological properties and can be a replacement for ordinary teas sold on the market. This study provides information on the choice of the plant morphotype and the cultivation area according to the needs of the consumer. Consumption of infusion of leaves from Korhogo and Béoumi that are richer in nutritional properties of the infusions (Toyosi et al., 2013).

Sensory evaluation and sensorial profiles of infusions: Tea Aroma, appearance and taste are the main parameters of it quality (Zheng et al., 2016). The variability of colour of infusion according localities corroborate result of Liang et al. (2007) who showed the variability of the colour of tea liqueurs from different origins. Infusions colour can be influenced by cultivar of plant, harvest season, climate and environmental conditions (Gao et al., 2016), that would explain the significant differences between the culture zones and the morphotypes. The variability of the aroma depending on the growing area has been observed by He et al. (2009) in infusions of $C$. sinensis leaves. Results differ from those of Ekissi et al. (2014) who working on spontaneous L. multiflora showed that infusions of Bondoukou leaves smelled of Ocimum gratissimum. This difference would be because the leaves were not picked during the same periods. The sensory profiles of the infusions of the leaves from the three localities show a significant difference $(P \leq 0.05)$ between the infusions, certainly because of the biochemical composition of the leaves, which varies according to the cultivation area. Indeed, any factor affecting the composition of tea leaves also influences that of infusions (Zheng et al., 2016).

tannins, catechin, quercetin and essential minerals (calcium, magnesium and iron) will be beneficial for human nutrition, bones strengthening and prevention of cardiovascular diseases which represent a public health problem. Taking Lippia multiflora into account in the agricultural and eating habits of farmers will constitute for them a source of income and also a source of permanent raw material for the agro-food processing industries

\section{ACKNOWLEDGMENTS}

The authors would like to thank the International Foundation for Science (IFS) for financial support (grant $\mathrm{N}^{\circ} \mathrm{C} / 5251$ 1).

\section{REFERENCES}

Adnan M, Ahmad A, Ahmed A, Khalid N, 2013. Chemical composition and sensory evaluation of tea (Camellia sinensis) commercialized in Pakistan. Pakistan Journal of Botany 45 (3): 901-907.

Alui KA, Yao-Kouamé A, Ballo KC, Kouadio KP, N'guessan KA, Nangah K Y, 2011.

Comportement de deux morphotypes de Lippia multiflora (verbénacée) sur ferralsols de la région de Yamoussoukro, Côte d'Ivoire. Journal of Applied Biosciences 38: 2592 - 2601.

Anuraga M, Duarsa P, Hill MJ, Lovett JV, 1993. Soil moisture and temperature affect condensed tannin concentrations and growth in Lotus 
corniculatus and Lotus pedunculatus. Australian Journal of Agricultural Research 44:1667-1681.

AOAC (Association of Analytical Chemists) 2000. Official methods of analysis. 17th ed:, Arlington, Virginia. USA, 2 (49): 1 -64.

Chakrabarty G, Bhattacharjeea S, Bhattacharyyaa S, 2017. Evaluation of antioxidant profile and phytochemical constituents of some herbsupplemented black tea infusions. International Journal of Pharmacy and Pharmaceutical Sciences 9 (12): 131-135.

Donovan JL, Meyer AS, Waterhouse AL, 1998. Phenolic composition and antioxidant activity of prunes and prune juice (Prunus domestica). Journal of Agricultural and Food Chemistry 46: 12471252.

Ekissi AC, Konan AG, Yao-Kouamé A, Bonfoh B, KatiCoulibaly S, 2014. Sensory evaluation of green from Lippia multiflora Moldenke leaves. European Science Journal10 (3): 534-543.

Gao L, Bian M, Mi R, Hu X; Wu J, 2016. Quality identification and evaluation of Pu-erh teas of different grade levels and various ages through sensory evaluation and instrumental analysis. International Journal of Food Science and Technology 51 (6): 1338-1348.

He W, Hu X, Zhao L, Liao X, Zhang Y, Zhang M, Wu J, 2009. Evaluation of Chinese tea by the electronic tongue: Correlation with sensory properties and classification according to geographical origin and grade level. Food Research International 42: 1462-1467.

Hien MP, YAO-Kouamé A, Yao NR, 2012. Incidence de l'alimentation hydrique sur la conduite des pépinières de graines de Lippia multiflora au Nord-est de la Côte d'lvoire (Bondoukou). Journal of Applied Biosciences 56: 4108-4117.

Kunle OF. and Egharevba HO 2012. Essential oil of Lippia multiflora Moldenke: A review. Journal of Applied Pharmaceutical Science, 2 (01): 15-23.

Liang Y, Wu Y, Lu J, Zhang L, 2007. Application of chemical composition and infusion colour difference analysis to quality estimation of jasmine-scented tea. International Journal of Food Science and Technology, 42: 459-468.

Mann A, 2014. Chemistry of Lippia multiflora (I) Moldenke essential oil compounds for industrial applications: a review. Proceedings of the International Academic Conference on Sustainable Development 2 (1): 13-14.
Mayouf JA, Al Bayati HS, Emmima EM, 2015. Quantitative Assessment of (Ca, Mg, K, Na, Fe, $\mathrm{Mn}$ ) in some brands of green tea marketed in Libya. ARPN. Journal of Science and Technology 5(6): 303-310.

Mossion A, 2007. Etude de la composition minérale et organique des liqueurs de thé et de leurs caractéristiques organoleptiques: Influence des paramètres physico-chimiques de l'eau. Thèse de doctorat, Institut National de Polytechnique, Université de Toulouse, France, 213 PP.

Oliveira RMM, 2012. Quantification of catechins and caffeine from green tea (Camellia sinensis) infusions, extract, and ready-to-drink beverages. Tecnol. Aliment., Campinas 32(1): 163-166,

Owuor PO, Kwach BO, 2012. Quality and yields of black tea Camellia sinensis L.O. Kuntze in response to harvesting in Kenya: a review. Asian Journal of Biological and Life Sciences 1 (1): 1-7.

Senthilkumar SR, Sivakumar T, Arulmozhi KT, Mythili N, 2015: Gas chromatography-mass spectroscopy evaluation of bioactive phytochemicals of commercial green teas (Camellia sinensis) of india, Asian Journal of Pharmaceutical and Clinical Research 8 ( 3) 278-282.

Toyosi D, Olu M, Alamu EA, 2013. Preliminary antibacterial and phytochemical screening of three medicinal plants used in the folkloric treatment of skin infections against three bacteria. Journal of Ethnobiology and Ethnopharmacology, 2 (1): 1-4.

Zheng XQ, Li QS, Xiang LP, Liang YR, 2016. Recent advances in volatiles of teas. A review. Molecules 21 (338): 1-12. 